\title{
Electronic Documentation of Learning: Alternate Reflective Discussion Formats
}

\author{
Ann Sherman and Angela Rokne
}

\section{University of Calgary}

\begin{abstract}
An electronic reflective journaling process is described here. Second year preservice teachers engaged with their professors through an electronic documentation of learning tool that was transformed over the period of a term. The practice of sharing, analyzing, deliberating, and making professional judgments in a supportive, on-line, reflective process enhanced the ability of these new teachers to truly grasp the experiences they were engaged in. The process invited them to explore their beliefs and practices in ways that moved them beyond the simple functioning as a teacher, to truly becoming a teacher.
\end{abstract}

Keywords: preservice teachers; electronic reflective journaling; teacher education 


\title{
Electronic Documentation of Learning: Alternate Reflective Discussion Formats
}

\author{
“Every time we begin, we wonder how we did it before." (Goldberg, 1986, p.5).
}

Few occupations offer as many opportunities as teaching does to start anew. Each year new students arrive and each year a teacher has once more an opportunity to think about activities and discussions, about ways to engage students that worked in previous years, and about those that caused pause for reflection. The following paper describes two professors' journey with a group of preservice teachers as they moved through the first year of a teacher preparation program. Together, they used an electronic journaling strategy termed "e dol" or "electronic documentation of learning" throughout the year. Reflection has become an increasingly important and valued practice in teacher preparation and teacher professional development. Along with an increased focus on reflection, comes new and innovative ways to enable such reflection. This electronic documentation of learning spawned new ways of reflecting together as a community of learners.

\section{Narrative Inquiry}

In this paper, we examine not only the strategy of e dol, but the learning community that was shaped by its use. This paper is not intended to be a research report on the use of e dol, but rather a narrative account of what transpired during the course. Clandinen and Connelly (2000) describe the dynamic and dialogical nature of narrative research in their definition of narrative inquiry.

Narrative inquiry is a way of understanding experience. It is collaboration between researcher and participants, over time, in a place or series of places, and in social interaction with milieus. An inquirer enters this matrix in the midst and progresses in this same spirit, concluding the inquiry still in the midst of living and telling, reliving and retelling, the stories of the experience that make up people's lives, both individual and social. Simply stated...narrative inquiry is stories lived and told. (Clandinen \& Connelly, 2000, p. 20)

We are two professors who engaged with a group of preservice teachers on a reflective journey and want to share the story of the professional and personal growth we saw and experienced with these student teachers. During the term, we discussed what was happening between ourselves and kept our own reflective notes on what we saw emerging. Our attempt here is to share the story of what we saw happening as a form of reflective electronic journaling supported the growth of a professional community of beginning teachers. Neil Postman's (1989) thoughts are helpful in directing attention toward story as a useful mode of representing the complexities of what we know.

If our stories are coherent and plausible and have continuity, they will help us to understand why we are here, and what we need to pay attention to and what we may ignore. A story provides structure for our perceptions; only through stories do facts assume any meaning whatsoever...Without stories as organizing frameworks, we are swamped by the volume of our own experience, adrift in a sea of facts. (pp. 122-123)

\section{Literature Review}

Students of teaching are generally urged to maintain a journal of observations, questions, ponderings, artifacts, and reflective writing from the field. Journal writing is considered significant in helping student teachers make personal sense of classroom practice (Pultorak \& 
Stone, 1999; Terrion \& Philion, 2008). Though many student teachers enter faculties of education unfamiliar with the practice of documenting their learning through journal writing, it is, as Carson (2001) notes, an accepted practice. "Narration and reflective practice are now commonplace in teacher-education programs” (p.77).

Francis (1995) suggests that the use of reflective journal writing helps develop preservice teachers as reflective practitioners. Journals allow student teachers to determine their own focus and what they want to understand, and to have their ideas seriously valued as knowledge being personally constructed. On-line forum discourses can also offer the opportunity to create a learning community (Zion, 2008).

Other research also suggests that electronic journaling provides a range of accessibility and support not offered in paper versions of journaling (Galanouli \& Collins, 2008). In their study, Galanouli and Colins found that the learning community that developed through a process of electronic journaling not only encouraged reflective teaching and an increased awareness of different technological systems, but also provided emotional support during student teaching.

Cowie (1997) concluded that the collaborative journal can be a useful tool for teachers' professional development, affording opportunities for reflection and integration not always available in oral interaction, yet still facilitating reflective dialogue between colleagues. Corley (2000) examined the use of electronic journaling practices with three specific areas of focus: (a) technical issues related to electronic journals; (b) attitudes toward e-journaling; and (c) suggestions for changes in the e-journaling process. Corley's results agree with other research on the effectiveness of journaling in promoting an increase in student reflective capabilities.

Some researchers suggest that student teachers should be taught explicitly about the discourses by which teaching is constructed so that they are able to reflect more critically on their professional practice (Pachler, Makoe, Burns, \& Blommaert, 2008); however, e dol is meant to enable and support a more emergent and thoughtful form of discourse, one that is bounded, yet flexible enough to promote exploration of ideas and understandings.

Research indicates that reflective dialogue is an alternative teacher professional development strategy, and that a teacher or student teacher's level of reflection is dependent on the his/her commitment to teaching, personal reasons and responsibilities. Teaching experiences also influences one's approach to reflective dialogue. It is suggested that if successful, reflective dialogue empowers teachers by enabling them to take control (understand/guide) of teaching and learning in their classrooms (Rarieya, 2005). Development of teaching expertise requires a disposition to engage in reflection on core beliefs, particularly but not exclusively within the domain of goals and purposes, the latter involving both communicative and emancipatory learning (Kreber \& Castleden, 1995).

Britzman's (2003) influential work, Practice Makes Practice, offers insight into the difficult terrains of teaching and student teaching and the rough ground that a student teacher must traverse between the two. She highlights the heavy work involved in becoming a teacher. She observes that most student teachers readily assume that they know what teaching entails. Teaching, she asserts, is a seemingly transparent profession. Her analyses of the cultural myths of teaching: "teacher as expert, everything is up to the teacher, the teacher is self made" (Britzman, 2003, p.223), produce scripts that "beckon and repel, promote and dispute, particular meanings about the work and the identity of the teacher" (p. 223). To imagine that becoming a teacher might issue a different sort of invitation, one that offers the uncertainty of subjectivity, 
narrative, ambivalence, contingency, and identity, invites a different kind of agency in exploring practice, a practice that alludes to being and becoming rather than simply functioning as teacher.

Propelled by the understanding that life in schools is never settled, Britzman's (2003) suggestion that, "Everyone in teacher education needs the space and encouragement to raise questions that attend to the possible and acknowledge the uncertainty of our educational lives" (p. 241) is both humane and hopeful. Britzman trusts that our quests will help us to "...begin to envision the discourses, voices, and discursive practices that can access the possible"(p. 241), creates a space for hope that we may do some good for our students, their future students and even for ourselves through our work in education.

Britzman's (2003) wry observation that "teacher education does not begin and end once students walk into schools of education” (p.238), when coupled with Carson's (2001) observation that it is not right to "simply abandoning student teachers to the practicum without retaining meaningful contact with the university" (Carson, 2001, p. 87), sends an instruction of profound responsibility to university instructors whose work it is to respond well to student teachers' field experiences. Smits' work (2001) helps us to understand the obdurate complexities of the work before us in learning to teach. He writes compellingly of student teachers whose stories

were much more complex and layered, and gave lie to the idea that reflection in theoretical terms could easily translate into a lived way of reflective practice, which was presumed to make learning both more personal and critical, was experienced as something distant and abstract when in the space of practice, students encountered difficulties which called for both deeper and more grounded practical understanding.....No matter how carefully the action research was conducted, as long as it focused on implementing a theoretical idea, the lived difficulties of student teaching persisted and indeed exceeded the conceptual understanding of reflective practice. (p. 283)

\section{The Context}

The University of Calgary's (U of C) B.Ed. Master of Teacher program has been shaped by the work of Britzman. The U of C Student Teacher Handbook describes the field journal as a place to "help students create a living record of their experiences...a site in which student teachers begin to envision who and what they might be as teachers" (Field Handbook, 2007/8, p. 46). As such, journal writing is described as "Creating a material culture of the everyday" (Field Handbook, p. 46). In this setting, field experiences alone are not seen to be places for learning to teach, nor even for practice teaching, but rather as sites of inquiry into what it might mean to teach and to learn. The field journal, then, is considered to be central to a student teacher's work in learning to teach. The journal becomes the lynchpin between field experience and university field seminars. The field seminar is offered as a space where students can critically unpack the assumptions, surprises, fears, and wonders of teaching and of classroom experience. Student teachers' journals, their questions, and debates in field seminar, necessarily forms and informs the work of the field instructor.

What might it mean to respond responsibly (Todd, 2003) to student teachers, their partner teachers, and the plurality of institutional narratives in which we are enmeshed? Todd's writing on the impact of response reminds us to listen to student teacher debate, conversation and writing with care. She notes, "if listening is part of a responsible response to another, then how might 
that response contribute to the larger sense of responsibility that social justice education continually strives for?” (p. 410).

This paper follows the work of a field group of fifteen student teachers and their instructors as it was shaped by the events that occurred when the form of journaling was changed from paper to an electronic documentation of learning.

\section{Reflective work with student teachers}

Initial conversations with each new field group attempt to open up narratives of being a child in school. Memories of being a student and being in a classroom doing science, math, art, language arts reveals stories of school practice which inevitably shape understandings of the disciplines, the work of teachers, the nature and the work of schools and, importantly, how all of these shaped understanding of self. "Teaching concerns coming to terms with one's intentions and values, as well as one's views of knowing, being, and acting in a setting characterized by contradictory realities, negotiation, and dependency and struggle” (Britzman, 2003, p. 8).

Each foray into school memories aims to direct student teachers' attention toward a collection of inheritances, some of which may be worth restoring while others, those that diminish learners and their learning, may be examined for their instruction and then cast aside. These early provocations are the initial invitations for student teachers to orient their questions and their studies in education toward thoughtful rather than replicative practice.

Learning to read the field context as a living text requires student teachers to open themselves up to their own and others' senses, and their own and others' beliefs and assumptions about everyday practice. Reading the field is difficult in that student teachers must find their questions in places that seemed ordinary, uncomplicated, usually safe and free from their own complexities. Learning to find questions where none existed before offers some challenge. Further, to participate in an education program that actively turns over ideas in ways that examines them from multiple perspectives is often foreign and discomforting to many student teachers. The field journal allows the student teachers to construct their own learning path guided by their instructors and conversations in field seminar. As Todd (2003) advocates, responsible response is a vital part of the journaling process. Sharing journal observations between students and trusted advisors helps expand student teachers' horizons.

Within this context, the field journal is a place where student teachers can select significant events amidst the torrent of classroom action and, from them, develop key questions and observations to understand more deeply these events in reference to teaching, learning, and self. Through journaling, the students can more readily see the importance of classroom action.

In keeping with the intent of the MT program, student teachers are encouraged to focus on how learning opportunities are taken up by different children and to consider how they might foster student learning, mediate struggles, and recognize the conditions that allow learning to flourish. It is in the reflective journal where the students explore and practice thinking for learning about teaching. It is here that good practical judgment about learners and learning begins to take root. Through months of careful recording and interpretation and attending to advisor response, the student teachers can anticipate multiple opportunities to develop understanding about how teaching in Canada is complex work that requires them to reflect on, and profit from, their own learning experiences to expand their understanding of 'teacher' and 'self as teacher'. They are then encouraged to reach beyond experience through further study to 
explore the possibilities that good teaching and learning might offer to learners in a complex, constantly changing, multicultural and democratic society.

\section{Electronic Journaling}

When an electronic mode of journaling called e dol (electronic documentation of learning) was first introduced, the field instructors were told that e dol was simply another form of journaling between student, partner teacher and field advisor but that it took place on-line. Supported by the free and open source content management system Drupal, e dol was explained to professors and instructors as a straightforward way to communicate with students about field experiences. Considerable effort was put into providing us with an accessible online manual and we were given superb ongoing technological support.

During the introductory workshops, discussion of the philosophical underpinnings for the change was scant. Emphasis was placed on proposed efficiencies. We were told that e dol would facilitate our work by avoiding difficulties surrounding circulating a paper journal between classroom teacher and field advisor, and that by working on-line we would fulfill the provincial knowledge, skills and attributes (KSAs) related to student teachers becoming familiar with "electronic teaching/learning technologies" (Field Handbook, 2007/08, p. 21). As well, we were encouraged to use e dol because it would be easier for us to assess student work from the single site. In general, field advisors were informed that e dol would ease the work.

For the student teacher experience, we were told that e dol would offer an ongoing documentation of their learning from which they could more easily gather important learning moments and uncover key themes as they created summative portfolios of their journey into teaching. No one had factored in the partner teachers' needs.

For the authors, none of the enticements of e dol were events to which we specifically needed solutions, nor did we see any apparent advantages over traditional journals for the student teachers with this new process. However, we decided that if the use of electronic journaling was mandated by the program, we would fulfil these obligations and do so with good will. In doing so, we felt we were modelling for the student teachers a form of co-operation that all teachers within school systems must learn to practice.

It became quickly apparent that e dol, in the way it was initially offered, was in many ways an encumbrance. Most of the student teachers experienced difficulty setting up the on-line journals and this caused stress and emotional distancing in the early weeks. Some students experienced difficulties in having ongoing access to a computer. Instead of collecting the work once per week in field seminar and returning it the following week, student responses appeared in a haphazard manner. Only one of the partner teachers ever responded to the students' work on-line, thus requiring the rest of the 14 student teachers to email or print copies of the journals for their partner teachers. It became more difficult for us to keep track of the response work and we felt distanced from the partner teachers' read and understanding of the students' work. This distancing resulted in a sense of lost trust.

Forms of student response also became constricted initially. Drawings, charts, asides, glued-in artifacts, and the play of three-way dialogue were all missing in the beginning stages of $\mathrm{e} \sim \mathrm{dol}$. The texture of the text had changed. In responding to their work, we could no longer dart in at the margins of pages with questions, brief suggestions, side comments or connect ideas with arrows. The responses, now severed from the body of students' texts, became necessarily more 
formal. Short comments needed moderating phrases to avoid sounding abrupt. Paragraphs, complete sentences, and full introductions locating responses to particular thoughts became essential. Instructor response time changed from one evening per week to hours daily.

At the same time, student work remained much the same as in previous years. Attuned students wrote with care; more hasty ones, less so. We responded in each student teacher's journal as usual, giving care to each one, acknowledging displayed wisdom, placing questions, suggesting readings, offering strategies; thus, beginning the slow methodical work of guiding student thinking about teaching and learning in classrooms. Responding through e dol seemed to offer nothing new or special and was lived out like a series of clumsy email exchanges.

\section{Field Seminar}

Field seminar changed with the new journaling format. Without beginning the seminar with the returned paper journals containing our responses, we could no longer set students in triads to share their work nor to find their common questions or moments of struggle and use these for whole class debate. Our ability to mediate with the group was deflected by absence of the paper journal and the distance of the electronic journal. Though this group had a typical range of personalities, interests and talents, we began to fear that we could lose connection with the student teachers as small issues arose.

It was through their shared experience brought forward in field seminar where we worked to push group thinking forward without causing undue threat to individuals. Field seminar has always been a tenuous ground for pushing against sedimented beliefs. Questions, and the ensuing conversations, must always be respectful of the partner teachers' classrooms and of the student teachers' allegiances to dubious practices such as, for example, use of rewards and punishment that seemed so successful in their field classrooms. As well, the student teachers who speak readily are not always the ones with the most insight to offer. Student teachers who wish to ask deep questions, or simply declare they do not understand, are often silent, or silenced. Every once in a while, one strong voice will block debate. At other times, conversations move too quickly to allow complex thoughts to be shaped or shared. Fimuara's (1990) observation that, "Any discourse initiated outside the dominant body of knowledge turns out to be so very difficult to think and articulate that it almost seems unheard-of, simply because it is unhearable: something only suitable for lapsing into madness or irrelevance” (p.55) seemed to hold true in field seminar.

It seemed to us that we could never quite create the conditions where the debates were as bountiful as we hoped they might be. It was a loss reluctantly accepted with hopes that even a glancing awareness of a question might lodge a provocation in student teachers' minds. Making field seminar more productive was an ongoing challenge we had set for ourselves.

\section{Creating an e dol Blog}

It was during one field seminar debate on the question, "Why do teachers read stories aloud in classrooms where children can already read?” that we realized e dol might help open a more fruitful space for further exploration. The in-class debate was wobbling along with many opinions and less thought when class time, as it always seemed to, ran out.

By now, it was half way through the first term, and we, with many other responsibilities, began to fatigue under the burden of the extra time needed for on-line response. Since the partner teachers were no longer responding to the field journals, we gave the student teachers a release 
from writing a field entry in their individually managed on-line field journals and asked, instead, that each of them write a paragraph on a whole class e dol blog in response to our unfinished inclass debate. This e dol blog was open only to the students and their professors during this time.

The results of this small on-line experiment exceeded our expectations. The writing that followed each question demonstrated an attention to the heart of the question that we had not experienced before. The slowness and formality that had been forced by e dol in the journal responses was echoed by the students. This now worked as an advantage for us. We were able to slow thinking down; hasty replies that eluded the question or risked embarrassing another no longer arose. Class debate experienced through e dol paused a while, everyone could speak, and more importantly, everyone could listen and consider theirs, and other's words, in their own time. Responses were richer and more respectful of other's thinking; thus, adding multiple layers of perspective on the question. One student reflects back noting,

With e dol as our platform for communication we were able to build on each others' thoughts more effectively than we could in a fast-paced classroom setting. We had the opportunity to read our classmates thoughts, reflect on them and perhaps gain a new perspective, and then shared our thoughts which furthered the reflections of other classmates. (e-mail communication, 2010 January)

The student teachers began to learn and to teach one another. Their responses were measured and noted with care of the other. Misunderstandings seemed less likely to occur.

We chose to respond to each student teacher's entry, instinctively understanding Fiumara's (1990) observation that, "We cannot possibly do without being heard" (p.175). We wanted the students to know that we continued to attend to them. The student teachers noted the tact of the dialogue and relaxed into the exacting work of rethinking teaching and learning. "I think you have been contemplating this all week long and are beginning to find living language for what you are now perceiving as an interactive engagement in learning” (Professor response, 2008 February 3). Now they could create a shared journal of inquiries and explorations that would not call into question any particular teachers' practice nor isolate any student teacher from exploring their views. We were all practicing responsible response (Todd, 2003). The whole class blog allowed a view into one another's thinking that had not previously occurred. None of the student teachers retreated behind the barricades of their own certainties or fears. Students who might tend to drift to the side of the group, stayed in the play of conversation continuing to engage as they realized that there were thoughtful views other than their own. All of the student teachers seemed to teach and learn from one another. They became more willing to engage in the provoking questions placed in their course outlines and experienced in their classrooms. For example, the question of why teachers read aloud brought forward ideas that showed evolved thinking on the part of the students.

They discussed the shared experience that stories bring to classrooms, the tranquility that story time creates, the imaginative scope and, the way that stories can support formal curriculum topics. One student brought forward the work of Jerome Bruner. In six years of teaching field seminar, this was the most engaged conversation generated on the topic as experienced by us.

For the next blog assignment, the student teachers were asked to create and respond to a small teaching event. They were asked to choose a book to read to their field class, explain why it was chosen, write a brief summary of the story, collect questions that arose from the story, and note how the children responded. A curious suite of questions arose from this aforementioned 
assignment: "Why was it that every student teacher had asked the children 'what would happen next, and, how would the story end?' and 'What is the purpose of such questions?' we asked them?” It was a stunning question for them to consider and to which none of them had an answer. It turned out that they were all simply asking those questions because those were the ones that teachers had asked to them. They had no idea how to develop the questions nor what they might reveal to learners. It was a revelatory moment, one that would never have occurred without the whole class e dol blog. Eventually we were able to open up this question and again the blog allowed expression to bloom.

Yet another question arose from the turmoil of the previous question. We asked the student teachers to consider why the assignment of choosing and reading a book to their field placement class was a worthwhile assignment. This too brought forward a moment of surprise that propelled us into deeper discussion in our field seminar. We began to see that our own teaching had slowed down, that we, too, were listening to the process of the work with deeper attention. We became aware that the students were finding voice in the sense that Britzman (1991) envisions whereby, "Voice... suggests the individual's struggle to create and fashion meaning, assert standpoints, and negotiate with others. Voice permits participation in the social world” (Britzman, 1991, p. 12). We began to see that through our use of e dol, the field seminar continued to do its work beyond the confines of the university classroom.

There was a level of trust created during this shared class e dol blog that followed the class through their year together. Although the bond was stressed several times, instead of fraying, it remained strong. The reflective practices of the student teachers developed in a manner that would serve them well as they entered their profession. The practice of sharing, analyzing, deliberating, and making professional judgments in a supportive, on-line, reflective process enhanced the ability of these new teachers to truly grasp the experiences they were engaged in. We are reminded of the words of Alastair McIntyre (1984):

I can only answer the question, "What am I to do?” if I can answer the prior question, “Of what story or stories do I find my self a part?” Children grow into adults by learning stories, and so do nations and communities...Deprive children of stories and you leave them unscripted, anxious stutterers in their actions as in their words...There is no way to give us an understanding of any society including our own, except through the stock of stories which constitute its initial dramatic resources. (MacIntyre, 1984, p. 215)

Our student teachers, it turned out, responded in ways we could not have predicted and wanted to re-tell the story of which they were a part. Perhaps the idea of the blog was more timely than we realized, fitting well with their personal interests in social networks. Stirred by their learning experiences, shared through the $\mathrm{e} \sim \mathrm{dol}$ class blog, they told their story beyond the classroom walls. On their own initiative, they researched how class blogs affect learning, and went well beyond the course expectations. Among other writers, they discovered work of Chickering and Ehrman (1996). That work, Implementing the Seven Principles: Technology as Lever, spoke strongly to the group's experiences. As a collective, they prepared a talk and power point presentation that served as a meta-analysis of the depth and breadth of the learning that flourished through their writing exchanges. In February 2008, seven of the fifteen students shared their work at WestCast, the Western Canadian Association for Student Teaching Conference. They ensured that voices of all their classmates were present. This presentation was evidence of the learning event's uniqueness and effect on these student teachers. 
As their professors, we felt we were able to contribute to each one individually and yet the contribution of the collective was also essential to success and growth. The process invited them to explore their beliefs and practices in ways that moved them beyond simple functioning as a teacher, to truly becoming a teacher. They lived out the stories they were experiencing by retelling them in new and different ways through the processes of this on-line, whole group reflection. Their experiences were powerful and supportive. The electronic journaling enabled their voices and stories to be shared and valued in a way that created strong bonds and encouraged professional growth through a supportive learning community. 


\section{References}

Britzman, D. P. (2000). Teacher education in the confusion of our times. Journal of Teacher Education, 51(3), 200-205.

Britzman, D. P. (2003). Practice makes practice: A critical study of learning to teach. New York: State University of New York Press.

Calandra, B., Brantley-Dias, L., \& Mcneal, K. (2008). An electronic system to support novice teachers' reflective lesson design, Multicultural Education \& Technology Journal, 1(2), 100111.

Carson, T. R. (2001). Reflection and its resistances: Teacher education as a living practice. In T. R Carson \& D. Sumara (Eds.), Action research as a living practice (pp. 77-91). New York, NY: Peter Lang Publishing Inc.

Carson, T., \& Johnston, I. (2001). Cultural difference and teacher identity formation: The need for a pedagogy of compassion. JPCS: Journal for the Psychoanalysis of Culture and Society, 6(2), 259-264.

Chickering, A.W., \& Ehrman, S.C. (1996). Implementing the seven principles: Technology as lever. AAHE Bulletin, 49(2), 3-6.

Clandinen, D. J., \& Connelly, F. M. (2000). Narrative inquiry. San Francisco, CA: Jossey-Bass.

Corley, E. L. (2001). A qualitative study of student perceptions regarding electronic journaling. Paper presented at the Annual Meeting of the Mid-Western Educational Research Association (MWERA). Chicago, IL.

Cowie, N. J. (1999). Collaborative journaling by email: Using the structure of cooperative development to become a more reflective teacher. Saitama University Review, 33(2), 199210.

Craig, C. J. (2008). Joseph Schwab, Self-study of teaching and teacher education practices proponent? A personal perspective. Teaching and Teacher Education: An International Journal of Research and Studies, 24(8), 1993-2001.

Fiumara, G. C. (1990). The other side of language: A philosophy of listening. (C. Lambert, Trans.). London, UK: Routledge.

Francis, D. (1996). The reflective journal: A window to preservice teachers' practical knowledge. Teaching and Teacher Education, 11(3), 229-241.

Galanouli, D., \& Collins, J. (2002). Using unmediated computer conferencing to promote reflective practice and confidence-building in initial teacher education. Journal of Information Technology for Teacher Education, 9(2), 237-254.

Goldberg, N. (1986). Writing down the bones: Freeing the writer within. Boston, MA: Shambala Publications.

Kreber, C., \& Castleden, H. (2009). Reflection on teaching and epistemological structure: Reflective and critically reflective processes in "Pure/Soft" and "Pure/Hard" fields. Higher Education: The International Journal of Higher Education and Educational Planning, 57(4), 509-531.

McIntyre, A. (1984). After virtue. Notre Dame, ID: University of Notre Dame Press. 
McIntyre, S. R., \& Tlusty, R. H. (1995). Computer-mediated discourse: Electronic dialogue journaling and reflective practice. Paper presented at The Annual Meeting of the American Educational Research Association. San Francisco, CA.

Pachler, N., Makoe, P., Burns, M., \& Blommaert, J. (2008). The things (we think) we (ought to) do: Ideological processes and practices in teaching. Teaching and Teacher Education: An International Journal of Research and Studies, 24(2), 437-450.

Postman, N. (1989, December). Learning by story. Atlantic Monthly, 119-124.

Pultorak, E., \& Stone, W. (1999). Understanding the realities of reflective teaching: What are best practices for the 21st century? Paper presented at The Annual Meeting of the Association of Teacher Educators. Chicago, IL.

Rarieya, J. F. A. (2009). Reflective dialogue: What's in it for teachers? A Pakistan case. Journal of In-service Education, 31(2), 313-336.

Sengupta, S., \& Nicholson, S. (1997). On-line and ongoing: Teacher development through TeleTeach. ELT Journal, 50(4), 290-302.

Smits, H. (2001). Living within the space of practice. Action research inspired by hermeneutics. In T. R Carson \& D. Sumara (Eds.), Action research as a living practice (pp. 281-293). New York: Peter Lang Publishing Inc.

Song, K. H., \& Catapano, S. (2008). Reflective professional development for urban teachers through videotaping and guided assessment. Journal of In-service Education, 34(1), 75-95.

Stein, S. J., Ginns, I. S., \& McDonald, C.V. (2008). Teachers learning about technology and technology education: Insights from a professional development experience. International Journal of Technology and Design Education, 17(2), 179-195.

Terrion, J. L., \& Philion, R. (2008). The electronic journal as reflection-on-action: A qualitative analysis of communication and learning in a peer-mentoring program. Studies in Higher Education, 33(5), 583-597.

Todd, S. (2003). Learning from the other: Levinas, psychoanalysis, and ethical possibilities in education. Albany, NY: State University of New York Press.

University of Calgary Bachelor of Education Master of Teaching Program. (2007/08). Field handbook. Calgary, AB: University of Calgary.

Zion, M. (2008). On line forums as a "rescue net" in an open inquiry process. International Journal of Science and Mathematics Education, 6(2), 351-375. 